\title{
Variation in the colour of the keel petals in Lotus corniculatus $\mathrm{L}$. 4. Morph distribution in the British Isles
}

\author{
Terence J. Crawford* and \\ David A. Jones $\dagger$
}

\author{
* Department of Biology, University of York, \\ York YO1 5DD, U.K. \\ $\dagger$ Department of Plant Biology and Genetics, \\ University of Hull, Hull HU6 7RX, U.K.
}

Keel-petal colour (dark versus light) in Lotus corniculatus L. has been scored for 125,503 plants at 1348 sites throughout the British Isles. The polymorphism shows strong and regular clinal change in morph frequencies. In all areas of western Britain and in southern England the majority of plants has light keels, particularly so in coastal regions. In eastern England, north of the River Humber, and in eastern Scotland dark-keeled plants predominate. Most off-shore islands conform to this pattern. Although the range in morph frequencies is virtually complete, monomorphism is unusual except in small samples, suggesting frequency-dependent selection in favour of the darkkeeled morph when rare. At least in Yorkshire, dark-keeled plants are. under-represented in the early stages of the flowering season; this is of doubtful evolutionary significance, although it is important in terms of sampling.

\section{INTRODUCTION}

European populations of Lotus corniculatus L. are usually polymorphic for keel-petal colour (Jones and Crawford, 1977). The keels may either be yellow, like the other petals ("light"), or may be pigmented towards the tip ("dark"). The difference is determined by a pair of alleles at a single locus that show a tetrasomic pattern of inheritance with the dark character dominant (Hart and Wilsie, 1959; Ramnani and Jones, 1984). Dark keels may reflect elevated concentrations of the anthocyanins delphinidin and cyanidin (P. Kakes, personal communication).

From the limited data available for continental Europe, the morphs appear to show no clear distribution pattern except that dark-keeled plants are often rare near the Atlantic and North Sea coasts (Jones and Crawford, 1977) but increase in frequency with altitude in the Alps, the Auvergne and in the Pyrenees (Baker and Jones, 1986). In England and Wales, however, Jones and Crawford (1977) observed that dark-keeled plants were more common in the north than in the south, while in Scotland the frequency of dark-keeled plants is greater in eastern regions than in the west (Abbott, 1981). A survey of 182 sites in Yorkshire and neighbouring counties (Crawford and Jones, 1986) revealed that the west to east cline, found in Scotland, is particularly evident in northern England.
In the west, around Morecambe Bay, dark-keeled plants are vitually absent whereas on Flamborough Head, in the east, their frequency is nearly 100 per cent. Along the cline, over a distance of some $210 \mathrm{~km}$, the morph frequencies change consistently, though not at a uniform rate; there seemed to be a relatively rapid increase in darkkeel frequency approximately $30 \mathrm{~km}$ inland from Morecambe Bay. It was unclear, however, whether this was related specifically to distance from the west coast or simply to longitude. Furthermore, the cline seemed weaker south of the River Humber; dark-keel frequencies of 60-75 per cent were typical for North Humberside, but were usually less than 50 per cent in South Humberside and Lincolnshire. Further south, such data as were available suggested that the west-east cline was virtually absent.

During the summers of 1985 and 1986 we made intensive surveys of populations throughout England and Wales and, to a lesser extent, in Scotland. The main aims were to determine whether morph frequency is related to coastal proximity, to establish the boundaries of the westeast cline typical of northern England and Scotland, and to confirm that the low frequencies of dark-keeled plants previously found in the few sites sampled in southern England were typical of populations throughout that region. 


\section{METHODS}

The intensity of pigmentation of dark keels is variable between plants, but flowers on the same plant show a uniform amount of pigmentation. It is possible to separate plants with pigmented keels into two categories: those with very light reddishbrown, diffuse pigment mainly confined to the leading edge of the keel tip ("pale") and those with a more even distribution of darker pigment ("dark"). At the extreme, plants may have a rich, chocolate-brown pigment extending almost to the base of the keel. This division is, however, somewhat subjective and pales and darks are genetically indistinguishable; the number of dark-keel alleles in the tetraploid genotype has no influence on the intensity of pigmentation (A. D. Ramnani, unpublished observations). Accordingly, pales and darks have been combined into a single dark class.

Because $L$. corniculatus can spread vegetatively plants were scored at a minimum distance of $1 \mathrm{~m}$ apart. No attempt was made to use the keel-colour character itself to distinguish between closely adjacent plants as this could introduce a bias against extreme morph frequencies.

In 1985 a set of instructions was circulated to a number of contacts, mainly professional botanists, asking them to collect data. A larger group of individuals participated in the 1986 survey in response to publicity in the national press. The problems over collecting and scoring samples were stressed and keels with any pigmentation, irrespective of intensity, were to be described as dark.

Sites were identified by their full National Grid reference (numerical co-ordinates of the $100 \mathrm{~km}$ square followed by the six-figure reference). Multiple records within a single $100 \mathrm{~m}$ square were treated as separate sites if it were known that different groups of plants had been scored; otherwise they were treated as replicates. This distinction affected how the data were to be treated. Results were combined for analysis and for pie chart display on a computer at four levels: morph ratios within $100 \mathrm{~m}$ National Grid squares within a given $1 \mathrm{~km}$ square; $1 \mathrm{~km}$ square totals, or individual sites, with in a given $10 \mathrm{~km}$ square; $10 \mathrm{~km}$ square totals within a $100 \mathrm{~km}$ square; and $100 \mathrm{~km}$ square totals for the entire British Isles. Separate sites maintained their independence during combination with data from other squares. With replicate sites, however, an appropriate pooling of data at the $100 \mathrm{~m}$ square level had to be reconciled with a fair contribution to totals at higher levels. The following procedure was adopted. The numbers of light- and dark-keeled plants were summed for all replicates in a $100 \mathrm{~m}$ square to provide a weighted mean frequency of the morphs. The total numbers of light- and dark-keeled plants were then scaled downwards to produce a single site record with a total number of plants equal to that in the largest individual sample, but with morph frequencies equal to their weighted means. For example, a pair of replicates with 60 light-keeled out of 100 plants, and 150 light-keeled out of 200 plants, yields a single record of 140 light-keeled plants in a sample of size 200.

Six sites near York (table 1) were selected for monitoring morph frequencies throughout the 1985 flowering season. The two Stamford Bridge sites were on a disused railway line separated by a break of about $100 \mathrm{~m}$ where a bridge had been demolished. The other sites were on broad roadside verges and banks. All populations were large and had been well-established for at least twelve years, except for Stamford Bridge 2 which has appeared more recently and is still expanding. Initially they were visited twice a week and all plants were scored. By mid-June many plants were flowering and the morph frequencies had become stable. Sites were then visited once a week and large samples of plants were scored; around midAugust flowering declined and once again complete surveys were attempted. The first ripe seed pods were collected from Stamford Bridge 1 and Scrayingham on 6 and 13 August 1985, respectively. Large samples of later-ripening pods ( $>100$ pods, one per plant), reflecting mid-season pollination, were collected from both sites on 9 September 1985. In the following Spring, all early seed and samples of later seed were germinated after scarification; the progeny were raised in a glasshouse and their keel colours were scored at flowering. The same six sites were revisited at twiceweekly intervals during the earlier part of the 1986 flowering season.

Table 1 Six sites in which $L$. corniculatus keel-colour frequencies were monitored during summer 1985 and early summer 1986

\begin{tabular}{|c|c|c|c|}
\hline Site & $\begin{array}{l}\text { National } \\
\text { Grid } \\
\text { reference }\end{array}$ & $\begin{array}{l}\text { Maximum } \\
\text { no. of } \\
\text { plants } \\
\text { scored } \\
\text { in } 1985\end{array}$ & $\begin{array}{l}\text { Average } \\
\text { dark-keel } \\
\text { frequency } \\
\text { in } 1985\end{array}$ \\
\hline Holtby 1 & $44 / 671533$ & 578 & 0.55 \\
\hline Holtby 2 & $44 / 678540$ & 560 & 0.65 \\
\hline Stamford Bridge 1 & $44 / 701558$ & 352 & 0.55 \\
\hline Stamford Bridge 2 & $44 / 702557$ & 116 & 0.42 \\
\hline Scrayingham & $44 / 742593$ & 506 & 0.57 \\
\hline Landing Lane & $44 / 583523$ & 160 & $0 \cdot 58$ \\
\hline
\end{tabular}




\section{RESULTS}

Including data from previous years (Crawford and Jones, 1986), at the end of the 1986 flowering season 125,503 plants had been scored at 1348 sites, treating replicate samples as above. Of these, 163 and 403 sites had been scored by 38 and 87 volunteers in 1985 and 1986, respectively. In addition, Dr R. J. Abbott generously provided full details on 60 of the 61 sites referred to in Abbott (1981). The remaining 722 sites were scored by the authors. Twenty-eight per cent of the National Grid $10 \mathrm{~km}$ squares in England and Wales are represented (484 out of about 1714 squares). Scotland is less complete; 254 sites have been scored in 15 per cent of $10 \mathrm{~km}$ squares (162 out of about 1059).

\section{Consistency of scorers}

Because so many scorers were involved, inconsistency in the scoring technique is a potential problem. The morph difference is, however, obvious and detailed instructions were sent to all scorers. We believe that the majority of records is reliable and this conclusion is supported by the data. Each of the volunteers' sites was checked to see if further data had been collected within the same $10 \mathrm{~km}$ square by other individuals, including ourselves treated as a single scorer. If so, homogeneity between scorers was tested by $\chi^{2}$ or
Fisher's exact test. Out of 87 tests, 26 were significant $(10$ at $P<0.05,7$ at $P<0.01$ and 9 at $P<0.001)$. This is a high proportion compared with chance but it must be remembered that different sites were involved, often a few kilometres apart. A further $13510 \mathrm{~km}$ squares contain two or more sites scored by the authors, but no sites by volunteers. For comparison, 87 of these were selected at random and tested for heterogeneity; 29 were significant ( 9 at $P<0.05$, at $P<0.01$ and 12 at $P<0.001$ ). This suggests an encouragingly high degree of consistency between scorers with any heterogeneity probably reflecting genuine site heterogeneity rather than different scoring techniques.

\section{Morph distribution}

The distribution of the two morphs is summarized in fig. 1. Each pie indicates the frequency of the dark-keeled morph for a $10 \mathrm{~km}$ square, records being pooled as described before. Combination at the $10 \mathrm{~km}$ square level is a fair compromise between providing a clear indication of geographical variation and minimizing the heterogeneity of pooled records; in fact, 54 per cent of pies are based on single sites. All $10 \mathrm{~km}$ squares are included irrespective of the number of plants scored. Reference to table 2 shows that other than a high frequency of monomorphism, to be discussed below, few irregularities result from

Table 2 National Grid $10 \mathrm{~km}$ squares with fewer than $25 \mathrm{~L}$. corniculatus scored for keel colour

\begin{tabular}{lrllll}
\hline $\begin{array}{l}\text { Square } \\
(100 \mathrm{~km} / 10 \mathrm{~km} \\
\text { co-ordinates })\end{array}$ & $\begin{array}{l}\text { No. of } \\
\text { plants }\end{array}$ & $\begin{array}{l}\text { Dark-keel } \\
\text { frequency }\end{array}$ & $\begin{array}{l}\text { Square } \\
(100 \mathrm{~km} / 10 \mathrm{~km} \\
\text { co-ordinates })\end{array}$ & $\begin{array}{l}\text { No. of } \\
\text { plants }\end{array}$ & $\begin{array}{l}\text { Dark-keel } \\
\text { frequency }\end{array}$ \\
\hline $08 / 77$ & 17 & $0 \cdot 00$ & $41 / 30$ & 20 & $0 \cdot 15$ \\
$10 / 71$ & 5 & $0 \cdot 00$ & $42 / 16$ & 19 & $0 \cdot 32$ \\
$10 / 86$ & 19 & $0 \cdot 11$ & $42 / 43$ & 16 & $0 \cdot 19$ \\
$10 / 93$ & 17 & $0 \cdot 24$ & $42 / 60$ & 16 & $0 \cdot 37$ \\
$16 / 79$ & 20 & $0 \cdot 15$ & $43 / 51$ & 9 & $0 \cdot 56$ \\
$16 / 82$ & 22 & $0 \cdot 32$ & $43 / 68$ & 9 & $0 \cdot 78$ \\
$17 / 84$ & 7 & $0 \cdot 14$ & $43 / 69$ & 22 & $0 \cdot 45$ \\
$19 / 23$ & 17 & $0 \cdot 00$ & $45 / 44$ & 8 & $0 \cdot 87$ \\
$22 / 04$ & 15 & $0 \cdot 33$ & $51 / 29$ & 18 & $0 \cdot 28$ \\
$27 / 04$ & 8 & $0 \cdot 00$ & $51 / 86$ & 12 & $0 \cdot 00$ \\
$27 / 05$ & 5 & $0 \cdot 20$ & $52 / 94$ & 18 & $0 \cdot 44$ \\
$27 / 16$ & 22 & $0 \cdot 14$ & $53 / 32$ & 20 & $0 \cdot 35$ \\
$27 / 17$ & 11 & $0 \cdot 45$ & $53 / 39$ & 17 & $0 \cdot 47$ \\
$28 / 64$ & 12 & $1 \cdot 00$ & $53 / 41$ & 8 & $0 \cdot 00$ \\
$28 / 98$ & 5 & $0 \cdot 00$ & $54 / 21$ & 9 & $0 \cdot 67$ \\
$31 / 57$ & 11 & $0 \cdot 09$ & $62 / 19$ & 13 & $0 \cdot 00$ \\
$35 / 87$ & 22 & $0 \cdot 64$ & $62 / 25$ & 14 & $0 \cdot 00$ \\
$37 / 04$ & 19 & $0 \cdot 89$ & $62 / 46$ & 10 & $0 \cdot 00$ \\
$40 / 69$ & 10 & $0 \cdot 00$ & & & \\
\hline
\end{tabular}




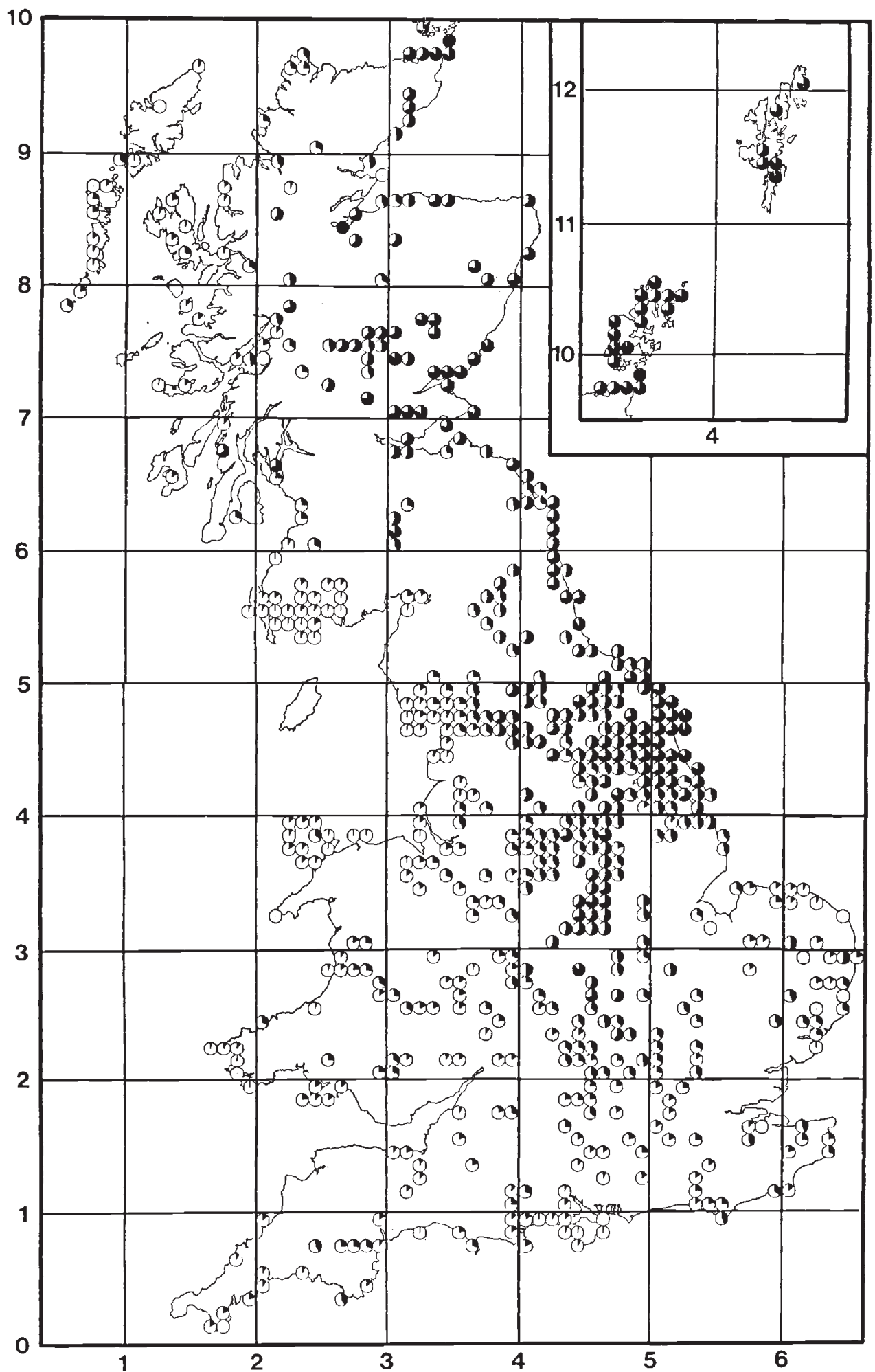

Figure 1 The distribution of the dark-keeled morph of L. corniculatus in the U.K. Co-ordinates refer to National Grid $100 \mathrm{~km}$ squares; data have been combined within $10 \mathrm{~km}$ squares as explained in the text. 
small sample sizes. Apart from Orkney and the Outer Hebrides, where there is some overlap of records, it is easy to identify Abbott's sub-set of data by reference to fig. 1 in Abbott (1981).

It is clear from fig. 1 that keel colour of $L$. corniculatus provides a dramatic example of a clinal polymorphism covering the entire British Isles. The frequency of dark-keeled plants is low throughout western regions and southern England. In eastern Scotland, and eastern England north of the River Humber, dark-keeled plants are in the majority. Frequencies are intermediate down the middle of the country as far south as the Midlands, and south of the River Humber in South Humberside and Lincolnshire. Morph frequencies are more variable in East Anglia than elsewhere, but seem on balance to conform with southern England. Data from Eire, the Channel Islands and the Isles of Scilly are not shown in fig. 1 and are presented in table 3. The dark-keel frequency in Eire seems typical of western Britain, and dark-keeled plants are almost absent from the Channel Islands. Both samples from the Isles of Scilly, however, contained a high proportion of plants with dark keels.
A late set of data for the Isle of Man covered 2491 plants from 19 sites; only $3 \cdot 4$ per cent of the plants had dark keels. Neither these data, nor those in table 3, are included in the following analyses.

A more quantitative description of the cline was attempted using a microcomputer display on which $10 \mathrm{~km}$-square symbols were mapped against an outline of the British Isles. The colour of each symbol depended on whether the dark-keel frequency in that square was below or above a specified value. A particularly clear segregation into areas of different colours occurred when the value was between 30 per cent and 40 per cent dark-keeled plants. As the chosen value progressively increased from 30 per cent, the boundary moved gradually eastwards and northwards; the number of non-conforming squares in the low dark-keel frequency area decreased whereas the number in the higher area increased. The total number of non-conforming squares in the two areas declined to a minimum at about 35 per cent before increasing again as the boundary value moved towards 40 per cent. This effect was particularly apparent when a margin of \pm 2 per cent was allowed

Table 3 Frequency of dark-keeled $L$. corniculatus in Eire, the Channel Islands and the Isles of Scilly

\begin{tabular}{|c|c|c|c|}
\hline Site & $\begin{array}{l}\text { Grid } \\
\text { Reference }\end{array}$ & $\begin{array}{l}\text { Sample } \\
\text { size }\end{array}$ & $\begin{array}{l}\text { Dark-keel } \\
\text { frequency }\end{array}$ \\
\hline \multicolumn{4}{|l|}{ (a) Eire } \\
\hline Cashel (Co. Connemara) & $\mathrm{L} / 80 ? 42 ?^{*}$ & 102 & $0 \cdot 10$ \\
\hline Fanore Sand Dunes (Co. Clare) & $\mathrm{M} / 138084$ & 100 & 0.06 \\
\hline Caher River Valley (Co. Clare) & $\mathrm{M} / 176047$ & 102 & $0 \cdot 10$ \\
\hline Ballykyno (Co. Mayo) & $\mathrm{M} / 116578$ & 100 & $0 \cdot 08$ \\
\hline Cloonkeen (Co. Clare) & $\mathrm{M} / 10 ? 86 ?^{*}$ & 100 & $0 \cdot 20$ \\
\hline Kinvarra Bay (Co. Clare) & $M / 364129$ & 173 & $0 \cdot 17$ \\
\hline Moylough (Co. Roscommon) & $\mathrm{M} / 558447$ & 100 & $0 \cdot 14$ \\
\hline Mount Bellew (Co. Roscommon) & $M / 693596$ & 117 & $0 \cdot 28$ \\
\hline Roscommon (Co. Roscommon) & $\mathrm{M} / 857605$ & 100 & 0.09 \\
\hline Skerries (Co. Dublin) & $0 / 245599$ & 100 & 0.07 \\
\hline Cliffs of Moher (Co. Clare) & $\mathrm{R} / 038921$ & 104 & $0 \cdot 22$ \\
\hline Cathaeir Chowien Fort (Co. Clare) & $\mathrm{R} / 27 ? 96 ?^{*}$ & 100 & 0.02 \\
\hline Loch Bunny (Co. Clare) & $\mathrm{R} / 378967$ & 50 & 0.08 \\
\hline Sherkin Island (Co. Cork) & $\mathrm{W} / 012244$ & 100 & $0 \cdot 19$ \\
\hline \multicolumn{4}{|l|}{ (b) Channel Islands } \\
\hline Les Etacs (Alderney) & WA/ 555065 & 237 & $0 \cdot 00$ \\
\hline Val du Sud (Alderney) & WA/ 572063 & 62 & $0 \cdot 02$ \\
\hline Brage Harbour (Alderney) & WA/ 576084 & 127 & $0 \cdot 00$ \\
\hline Brage Beach (Alderney) & WA/ 583081 & 65 & 0.06 \\
\hline St. Ouen's Pond (Jersey) & WA/ 567524 & 100 & 0.05 \\
\hline Telegraph Bay (Alderney) & WA/ 603063 & 72 & 0.00 \\
\hline Veaux Tremliers Bay (Alderney) & $\mathrm{WA} / 601091$ & 56 & $0 \cdot 00$ \\
\hline Fort Quesnard (Alderney) & WA/ 606091 & 74 & 0.03 \\
\hline \multicolumn{4}{|l|}{ (c) Isles of Scilly } \\
\hline Appletree Banks (Tresco) & $00 / 893135$ & 50 & 0.64 \\
\hline Old Town (St. Mary's) & $00 / 917102$ & 50 & 0.70 \\
\hline
\end{tabular}

\footnotetext{
* Grid reference known only to $1 \mathrm{~km}$ square accuracy.
} 
in identifying non-conforming squares. It suggests a boundary (see fig. 2) over which morph frequencies change more rapidly than they do over greater distances on either side; at least it provides a less subjective criterion for describing the geographical variation.

It proved impossible to find a clear boundary between areas of intermediate and high dark-keel frequencies. As the boundary value was increased from 60 to 70 per cent the number of non-conforming squares in the higher area remained roughly constant while that in the lower area gradually declined. Between 63 and 67 per cent, however, this decline was almost absent. For descriptive purposes, therefore, a boundary of 65 per cent has been chosen for dividing intermediate and high dark-keel frequency areas. Admittedly, this is a more subjective boundary, particularly as many of

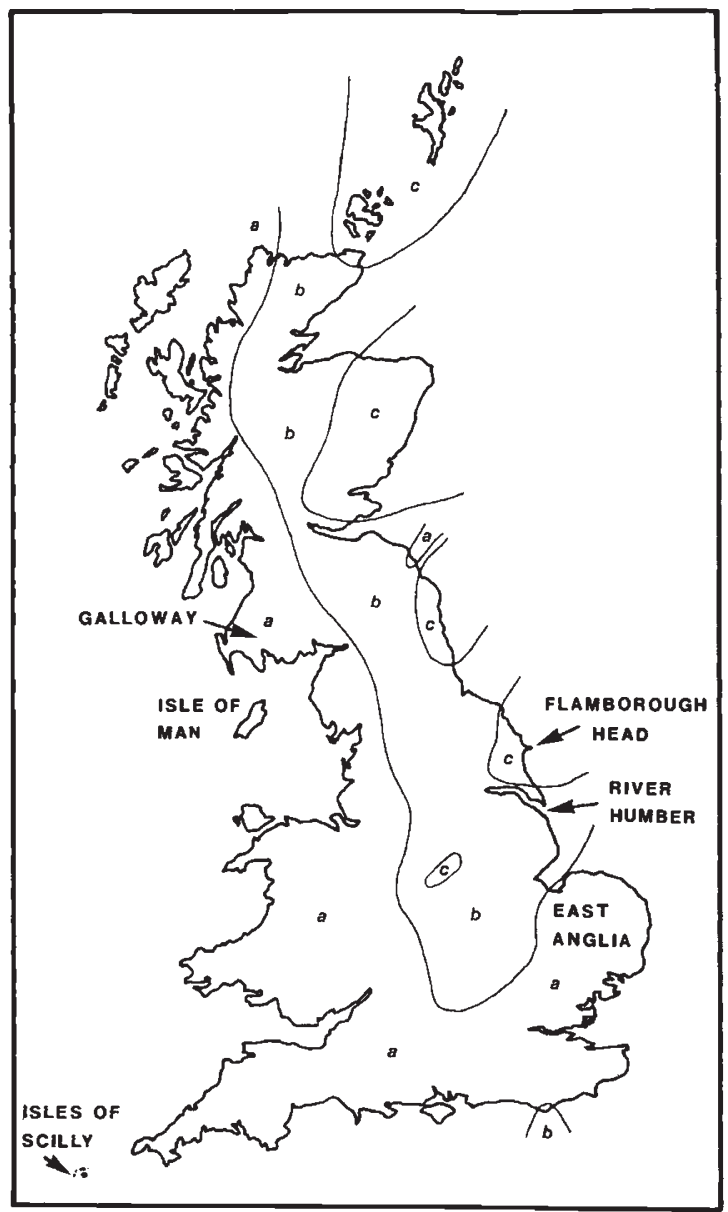

Figure 2 Approximate boundaries separating areas of the U.K. where the dark-keel frequency of $L$. corniculatus is (a) $0 \cdot 0-0 \cdot 35$, (b) $0 \cdot 35-0 \cdot 65$, (c) $0 \cdot 65-1 \cdot 0$. the non-conforming squares occur at some distance from it. Fig. 2 shows that high frequencies of dark-keeled plants are found mainly in northeast England and eastern Scotland. In addition, an area in the Midlands, which can also be seen in fig. 1 (100 km square 43), forms a clear exception to the general clinal pattern; an "island" of high dark-keel frequency, individual sites varying from 58 to 79 per cent, is surrounded by lower frequencies.

Two further exceptional areas have been identified within which a number of sites deviates consistently from surrounding regions. In southern England most sites contain 25 per cent, or fewer, dark-keeled plants. On Beachy Head, however, seven sites over a distance of $4 \mathrm{~km}$ along the coast show higher frequencies with an average of 45 per cent (fig. 3). It is not known how far inland this area extends. Conversely, high frequencies of darkkeeled plants are typical of north-east England, but in a small area of Northumberland, including Lindisfarne and the adjacent mainland, the frequency is reduced to about 30 per cent (fig. 4).

The general impression of the cline, as shown in fig. 2, can be judged by the proportion of $10 \mathrm{~km}$ squares whose weighted average dark-keel frequency lies within the limits imposed by the 35 and 65 per cent boundaries. 560 out of the 632 $10 \mathrm{~km}$ squares shown in fig. 1 conform (89 per cent); if the \pm 2 per cent used in establishing the boundaries is allowed, 574 squares ( 91 per cent) conform. The 35 per cent boundary is approximate

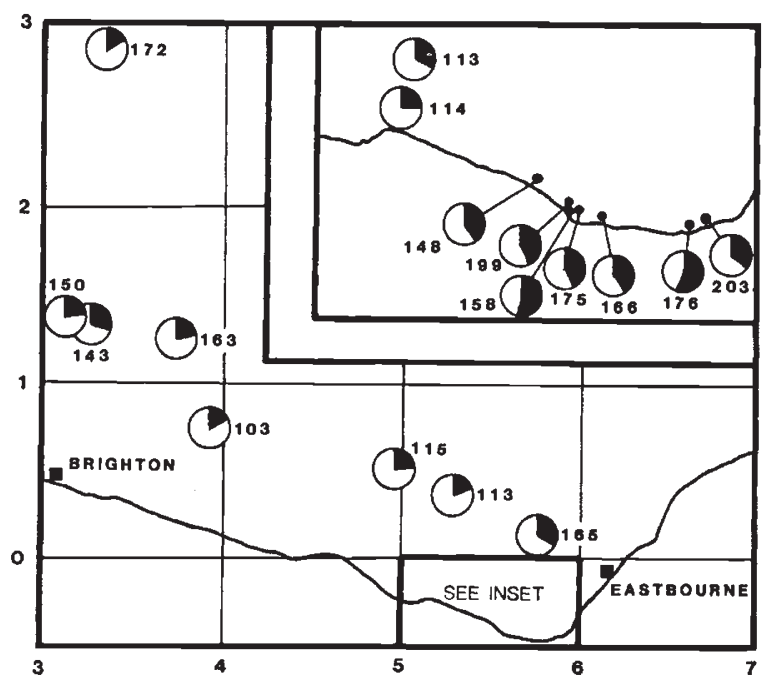

Figure 3 The area of high frequency of dark-keeled $L$. corniculatus at Beachy Head (inset), Sussex. Sample sizes are indicated by each pie. Co-ordinates refer to National Grid $10 \mathrm{~km}$ squares within $100 \mathrm{~km}$ squares 50 and 51 (see fig. 1). 


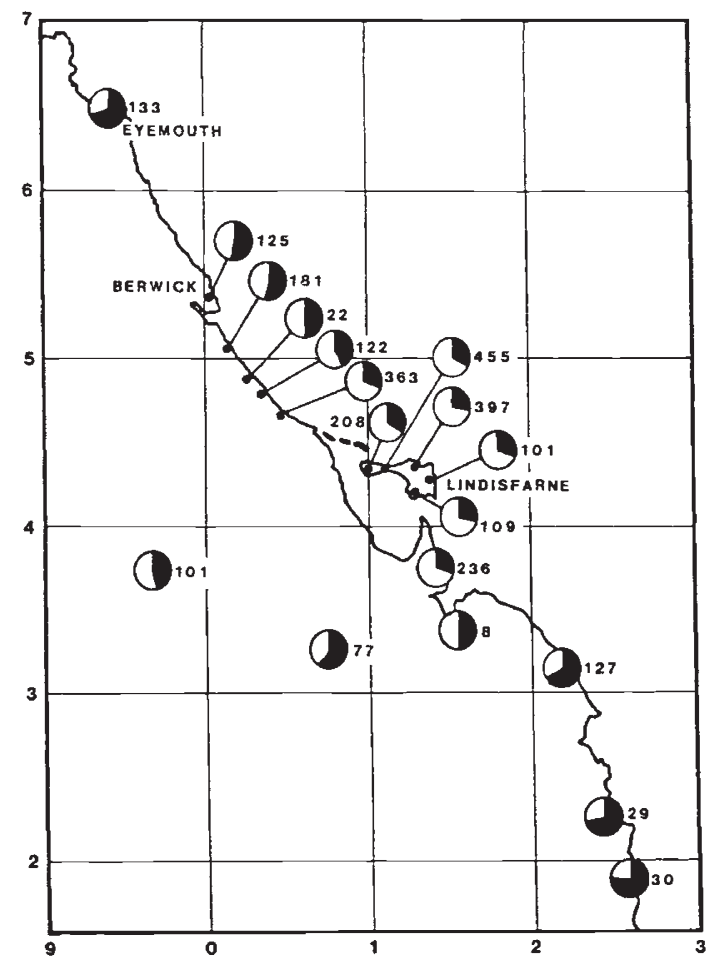

Figure 4 The area of low frequency of dark-keeled $L$. corniculatus in Northumberland. Sample sizes are indicated by each pie. Co-ordinates refer to National Grid $10 \mathrm{~km}$ squares within $100 \mathrm{~km}$ squares 36 and 46 (see fig. 1).

in much of Scotland but can be fixed more precisely in England and Wales where there are many records in western and southern regions. It is clear that the 35 per cent boundary is independent of distance from western or southern coasts.

There is, however, a tendency for sites with very low frequencies of dark-keeled plants to be coastal. Sites were identified where at least 25 plants had been scored and the frequency of darkkeeled plants was 10 per cent, or fewer. Of all the sites in the survey, 118 fell into this category. Their distances from the closest point on western, southern, or East Anglian coasts were measured to the nearest $1 \mathrm{~km}$, estuaries being regarded as coastal only if the river was at least $10 \mathrm{~km}$ wide. The mean distance from the coast was only $7 \cdot 1 \mathrm{~km}$.

Although high dark-keel frequencies are typical of north-east Britain, the pattern is not as regular as that of the low dark-keel frequency area in the west and south. Figs. 1 and 2 suggest four areas of particularly high frequencies of dark-keeled plants, 65 per cent or more, interspersed by areas of more intermediate frequencies. These latter areas seem to be associated with changes in the orientation of the coastline more towards a westeast axis.

There is a striking.discontinuity in the region of the River Humber in $100 \mathrm{~km}$ square 54, North Humberside populations in general showing greater frequencies of dark-keeled plants than populations in South Humberside and Lincolnshire. The discontinuity is not, however, coincident with the River Humber. This is shown particularly clearly on the Spurn Peninsula which, although connected to North Humberside, extends southwards for several $\mathrm{km}$ into the River Humber to a distance consistent with South Humberside latitudes (fig. 5). The frequencies of dark-keeled plants along the peninsula are similar to those in South Humberside, but only a few km north from the peninsula they have increased to levels typical of north-east England.

\section{Variation in morph frequency during flowering season}

Fig. 6 shows the frequency of dark keels amongst flowering plants during early summer in 1985 and 1986 in the six sites near York which were visited

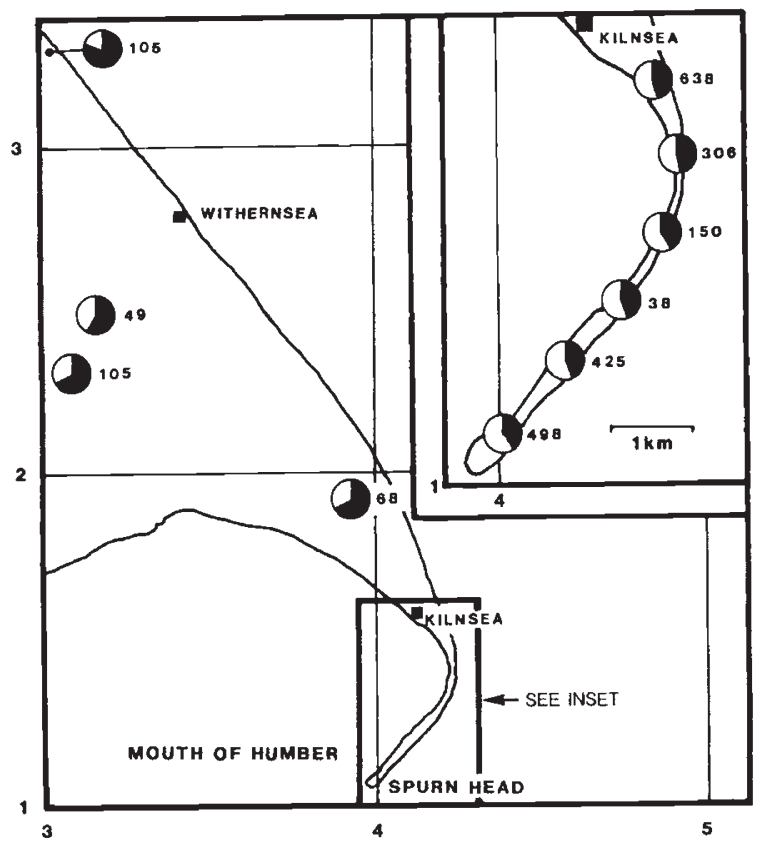

Figure 5 The frequency of dark-keeled $L$. corniculatus on the Spurn Peninsula (inset) and in nearby North Humberside. Along the peninsula data have been combined within $1 \mathrm{~km}$ strips measured from the tip. Sample sizes are indicated by each pie. Co-ordinates refer to National Grid $10 \mathrm{~km}$ squares within $100 \mathrm{~km}$ square 54 (see fig. 1). 

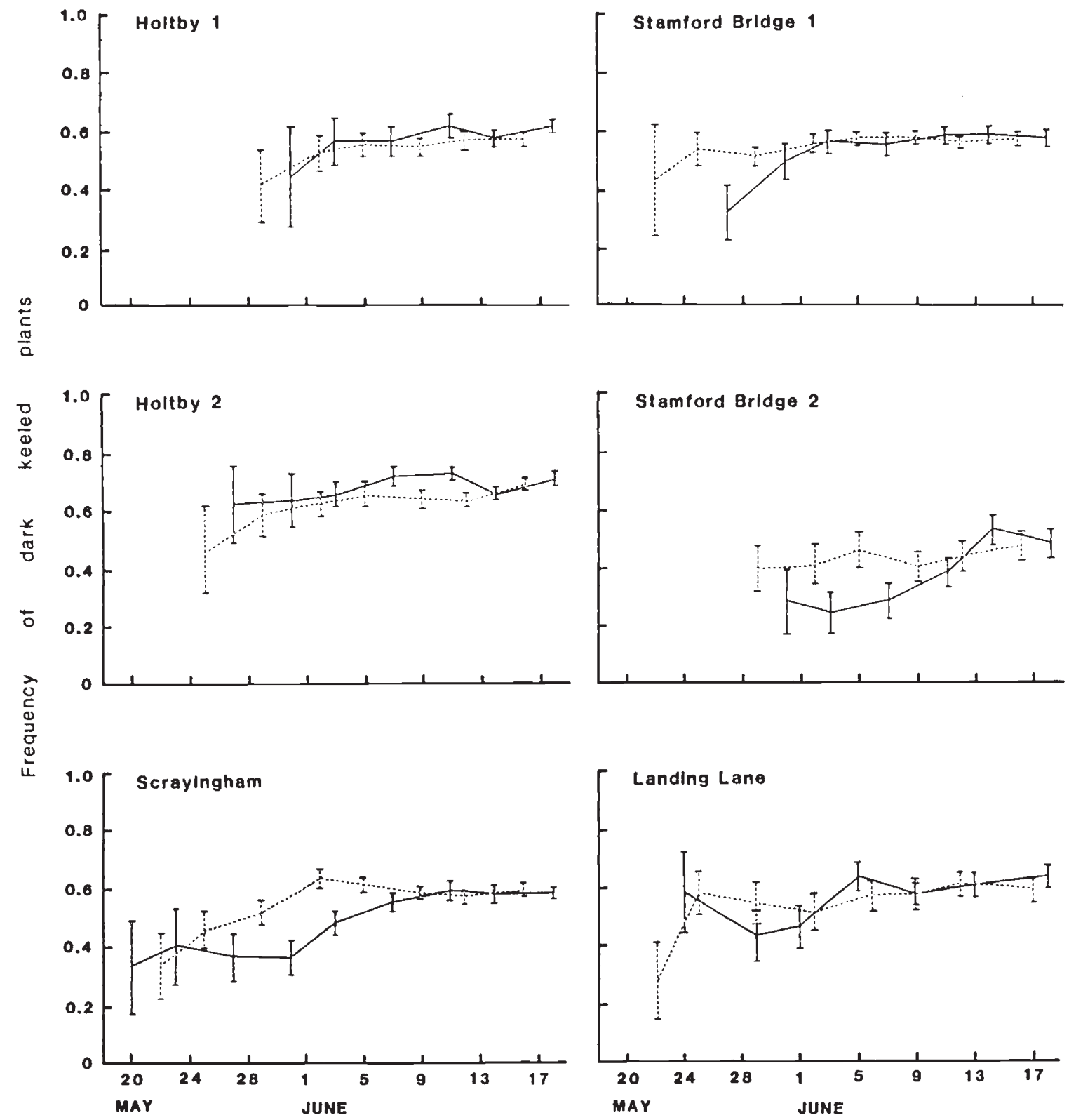

Figure 6 The frequency of the dark-keeled morph of $L$. corniculatus at six sites near York during the earlier part of the flowering season in 1985 (continuous line) and 1986 (broken line). Error bars indicate \pm 1 standard error.

regularly. The proportion of dark-keeled flowering plants in general increased through late May and early June in both years. Further sampling in 1985 suggested that it subsequently remained constant until the end of the flowering season. Flowering commenced at different times in the six sites and these differences were consistent between the two years.

The purpose of the early and later seed collections at Stamford Bridge 1 and Scrayingham was to see if the initial deficiency of dark-keeled plants would be reflected in the progeny. The viability of early seeds was poor (see Table 4) and they yielded an average of only 2.8 progeny per pod at Stamford Bridge 1 and 0.9 at Scrayingham. These compare with minimum estimates of 11.0 and $4 \cdot 2$, respectively, for the later collected seed. One early set of 22 pods from a single dark-keeled parent at Stamford Bridge 1 showed higher germination ( $5 \cdot 3$ progeny per pod) and also a very high frequency of 
Table 4 The frequency of dark-keeled $L$. corniculatus progeny from early- and later-collected seed at Stamford Bridge 1 and Scrayingham. Also included are the maximum parental sample sizes and the weighted average dark-keel frequency during 1985

\begin{tabular}{|c|c|c|c|c|c|c|}
\hline & $\begin{array}{l}\text { No. of } \\
\text { ovule } \\
\text { parents }\end{array}$ & $\begin{array}{l}\text { No. of } \\
\text { pods }\end{array}$ & $\begin{array}{l}\text { Progeny } \\
\text { per pod }\end{array}$ & $\begin{array}{l}\text { No. } \\
\text { scored }\end{array}$ & $\begin{array}{l}\text { Dark-keel } \\
\text { frequency }\end{array}$ & $\begin{array}{l}\chi^{2}(1 \mathrm{df}) \text { for } \\
\text { comparison } \\
\text { with parents }\end{array}$ \\
\hline \multicolumn{7}{|c|}{ (a) Stamford Bridge 1} \\
\hline Early seed & 25 & 234 & $2 \cdot 8$ & 652 & 0.56 & \\
\hline Early seed* & 24 & 212 & $2 \cdot 6$ & 537 & 0.47 & $4.9 P<0.05$ \\
\hline Later seed & 103 & 103 & $>11 \cdot 0$ & 120 & 0.53 & $0.2 \mathrm{~ns}$ \\
\hline Parents & & & & 352 & 0.55 & \\
\hline \multicolumn{7}{|c|}{ (b) Scrayingham } \\
\hline Early seed & 30 & 177 & 0.9 & 161 & 0.40 & $13.4 P<0.001$ \\
\hline Later seed & 112 & 112 & $>4 \cdot 2$ & 115 & 0.55 & $0.2 \mathrm{~ns}$ \\
\hline Parents & & & & 506 & 0.57 & \\
\hline
\end{tabular}

* Progeny of one parent excluded (see text).

dark-keeled progeny (108 out of 115); presumably the parent was triplex for the dark-keel allele. Because these progeny were unusual in these two respects, and accounted for 17 per cent of the total Stamford Bridge 1 progeny, it was felt best to exclude them. The early progeny then showed a significant dark-keel deficiency compared with the weighted average parental morph frequencies during summer 1985; later progeny conformed to parental frequencies (see table 4). Similar results were obtained for Scrayingham. The date of the first flower was recorded for all progeny grown from the later collected seed. There was absolutely no difference between light- and dark-keeled morphs from either population in flowering time when grown under glass.

\section{DISCUSSION}

There are few genetic polymorphisms where the distribution of morph frequencies throughout the British Isles is known in such detail as is now the case with the keel-colour polymorphism of Lotus corniculatus. Other examples where large surveys have been conducted, or where data have accumulated over a number of studies, include the human blood group polymorphisms (Kopec, 1970), shell colour and banding patterns in Cepaea (Jones, Leith and Rawlings, 1977), melanism in Biston betularia (Kettlewell, 1973) and abdominal colour and pattern in the spider Enoplognatha ovata (Oxford, 1985). Geographical variation in morph frequencies has been found in each of these examples. The blood group $\mathrm{O}$ frequency increases northwards and westwards between about 43 and 51 per cent, while group A conversely declines between about 45 and 31 per cent. The yellow shell frequency of $C$. nemoralis shows some variation related to mean July temperature when data are combined within $100 \mathrm{~km}$ grid squares; at the more local level, however, extreme variation in morph frequencies often occurs over short distances (Cain and Currey, 1963). The redimita morph of E. ovata decreases in frequency along a south-east to northwest axis in England and Wales, and decreases from east to west in Scotland. But the clines are weak with $100 \mathrm{~km}$ square frequencies varying from about 10 to 33 per cent.

The frequency distribution of the keel-colour morphs shares with melanism in $B$. betularia a combination of features that makes it a particularly interesting example of a clinal polymorphism. The morph frequencies show simple gradation throughout the majority of the British Isles, and with few local perturbations from the general pattern. There are, however, regions of more rapid change: in $B$. betularia, for example, between the Wyre Forest and Birmingham (Kettlewell, 1973) and from North Wales to Liverpool (Bishop, 1972), and in L. corniculatus in the region of the River Humber. In both $L$. corniculatus and $B$. betularia the range in morph frequencies is virtually complete. Other well-studied clines do not show all of these features. The north-south decline in the melanic $f$. edda of the moth Amathes glareosa in Shetland, while complete, is restricted to those islands (Kettlewell and Berry, 1961). Most populations of the grasshopper Myrmeleotettix maculatus in sou.hern England and the Midlands are poly- 
morphic for B-chromosomes which are present in 40 to 50 per cent of individuals; B-chromosomes are absent in areas where summers are cooler. It is only where these two stabilizations meet that sharp clines are found, as in East Anglia (Hewitt and Brown, 1970). Although there is a considerable variation in the frequency of melanic Adalia bipunctata ladybirds, clinal patterns are irregular and not always associated with industrial conurbations (Creed, 1971). Selection is not related to airborne sulphur dioxide, but rather to the cooling effects of local smoke pollution being superimposed on geographical climatic gradients (Muggleton, Lonsdale and Benham, 1975; Brakefield and Lees, 1987).

Some clines show only weak gradients in morph frequencies across the British Isles because they are merely extensions of large-scale continental clines. This is so for shell colour in Cepaea nemoralis (Jones, Leith and Rawlings, 1977), allele frequencies considered jointly for six enzyme systems in C. nemoralis and C. hortensis (Ochman, Jones and Selander, 1987), the bridled variant of the guillemot Uria aalge (Southern, 1962), cyanogenesis in Trifolium repens (Daday, 1958), and for human blood groups (Mourant, Kopec and Domaniewska-Sobczak, 1976).
In the case of geographically extensive clines, an association between morph frequencies and climatological factors is often an attractive hypothesis. Changes with latitude should then be reflected by changes with altitude, as with cyanogenesis in $T$. repens (Daday, 1954a,b) and two seed-coat characters, presence or absence of papillae and degree of hairiness, in Spergula arvensis (New, 1958, 1978). By contrast, although L. corniculatus populations are polymorphic for keel colour throughout western Europe, regular geographical clinal change in morph frequencies seems to be restricted to the British Isles (Jones and Crawford, 1977 and unpublished data). In the Alps, the Pyrenees and the Auvergne, however, there are rapid increases in dark-keel frequency at higher altitudes (Baker and Jones, 1986). Allowing for the higher latitudes of the British Isles, similar associations might be expected at lower altitudes, but they seem to be absent (figs. 1 and 2). Fig. 7 shows dark-keel frequencies and altitudes along a west-east transect in northern England. Taking as a base-line the National Grid $460 \mathrm{~km}$ northing, the data in each $10 \mathrm{~km}$ square were combined with those of the next two neighbouring squares to the north. The choice of a strict west-east orientation was arbitrary and does not necessarily coincide

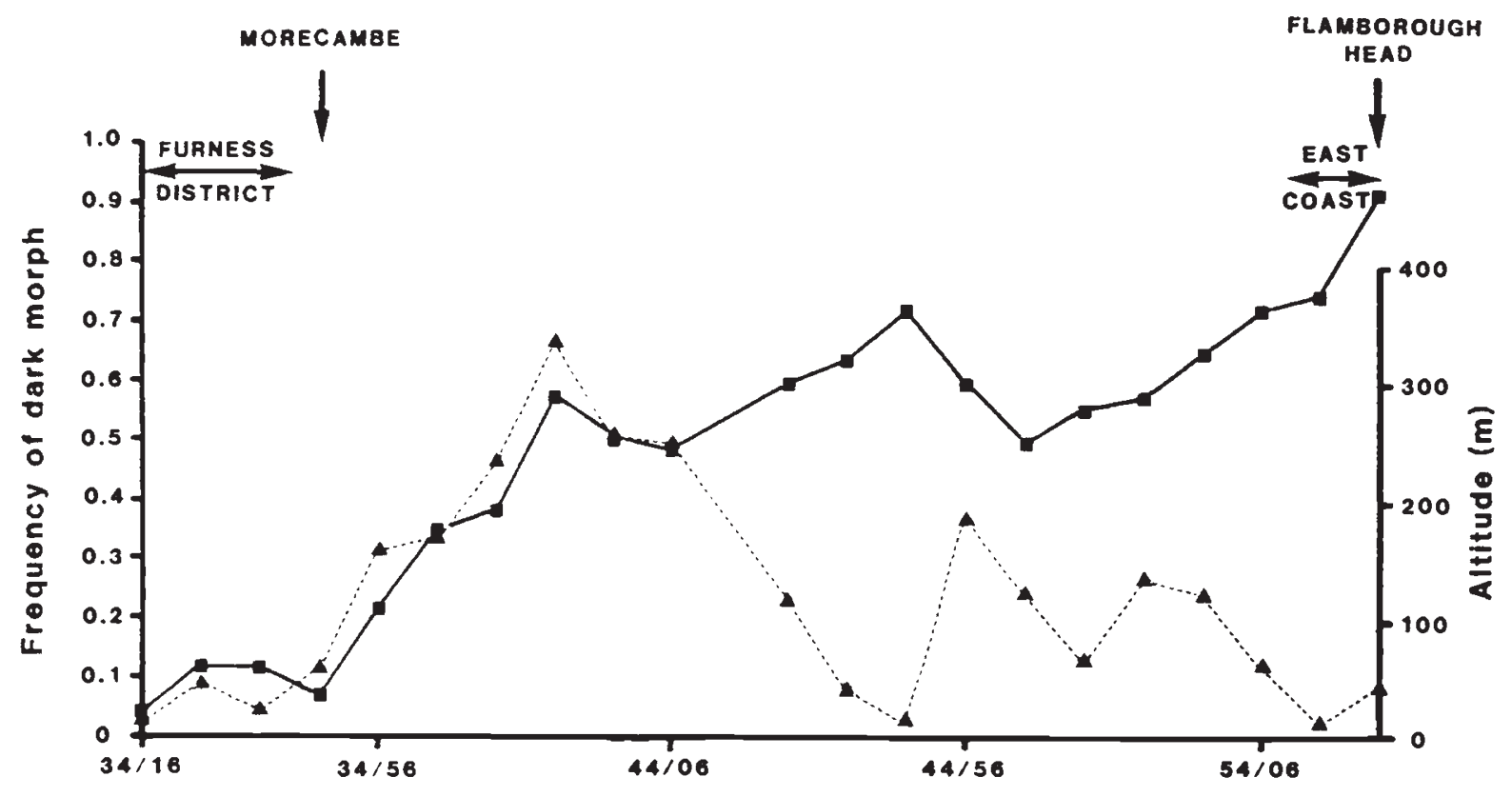

$10 \mathrm{~km}$ square co-ordinates on base line

Figure 7 The frequency of the dark-keeled morph ( $\square$ ) and altitude ( $\left.\boldsymbol{\Delta}_{-}-\mathbf{\Delta}\right)$ along a west-east transect in northern England. The base-line is the National Grid $460 \mathrm{~km}$ northing. Morph frequencies and site altitudes have been averaged within strips $10 \mathrm{~km}$ wide and extending $30 \mathrm{~km}$ northwards from the base-line. 
with the direction of maximal clinal gradient. Within each $10 \mathrm{~km} \times 30 \mathrm{~km}$ strip, dark-keel frequencies were averaged over sites, weighting by the inverses of their binomial variances; site altitudes were averaged, weighting by the inverses of the sample sizes. There is no association between keel colour and altitude except over the first $40 \mathrm{~km}$ inland from Morecambe Bay in the west. In this region the dark-keel frequency increases through the 35 per cent boundary as altitude rises onto the Pennine Hills. This is probably a chance association because both to the north, in Galloway, and also to the south, in Wales, there are no similar changes in morph frequencies even though altitudes increase away from the coast; the 35 per cent boundary is farther to the east in these regions.

While altitude would appear to have little direct influence on keel-colour frequencies in the British Isles, coastal proximity certainly does, at least along western, southern and East Anglian coasts. Populations with very low dark-keel frequencies (10 per cent, or fewer) are largely restricted to these coastal strips, although higher frequencies are not precluded. Data for continental Europe are limited but there is again some evidence that very low dark-keel frequencies are associated with the Atlantic coasts of Spain and France, and coastal areas of The Netherlands and West Germany (Jones and Crawford, 1977).

The suggestion that there are areas where keelcolour frequencies change more rapidly over distance is of interest and worthy of closer investigation. This is particularly so in North and South Humberside where an abrupt change occurs near a major geographical barrier, the River Humber and the low-lying fenland area to the south of the estuary where $L$. corniculatus is thinly distributed. The rapid change in morph frequencies over distance does not coincide with the estuary, but steps in clines can be displaced relative to the barriers that generate them (Endler, 1977). The marked genetic differentiation in the region of the Spurn Peninsula (fig. 5) might reflect stochastic effects arising from the approximately 250 -year cycle of sand-spit development followed by destruction at the mouth of the Humber (de Boer, 1963, 1968); the present peninsula is about 350 years old, its life-span having been extended by conservation measures since the $1850 \mathrm{~s}$. On the other hand, genetic differentiation in response to a selective gradient is expected to proceed more rapidly in what is essentially a linear habitat.

A particular effort was made to obtain data from islands because, if selective influences are weak, chance factors may lead to local deviations, especially on small, isolated islands (Williamson, 1981). Fig. 1 and table 3 show that data have been collected from many islands, large and small, and more or less isolated from the mainland. It is clear that islands generally conform to the national picture, and this suggests that strong selective forces may determine keel-colour frequencies in the British Isles. Lindisfarne (fig. 4) is probably not completely isolated from the mainland, but it seems, nevertheless, significant that the abnormally low dark-keel frequencies found on that island in north-east England are part of a local discontinuity that also includes the adjacent mainland. The nearby, small and more isolated Farne Islands now need to be sampled. The only island samples that show marked deviations from the general pattern are those on the Isles of Scilly; the scorer has considerable experience with the keel-colour polymorphism (Harry Vallack-see Acknowledgements). Given that some local discontinuities have been found on the mainland, it is difficult to judge the significance of this isolated exception. At least, the need for a closer investigation of keel-colour frequencies on these islands is indicated; they are well-known sites for local genetic differentiation in other species (Ford, 1975; Berry, 1977).

The keel-colour cline in the British Isles embraces the complete range of morph frequencies, yet rather few sites are monomorphic. Lightkeel monomorphism was found at 41 sites, but on average only 23 plants were scored at these sites; only in four cases were more than 50 plants scored. By comparison, 45 sites were polymorphic, but with 5 per cent, or fewer, dark-keeled plants, and these sites had an average sample size of 96 plants. There were only three sites monomorphic for dark keels with sample sizes of 9,10 and 12 plants. Bearing in mind that for the entire survey an average of 93 plants per site has been scored, it seems clear that monomorphism is largely a feature of small sample sizes, or small populations.

The description of clinal variation has been in terms of morph frequencies rather than allele frequencies. Because $L$. corniculatus is an autotetraploid (Dawson, 1941) and the keel-colour morphs show tetrasomic inheritance (Hart and Wilsie, 1959; Ramnani and Jones, 1984) variation in allele frequencies will be less marked than that in phenotype frequencies, though similar in general pattern. The light-keeled morph is recessive; when it is rare the vast majority of light-keel alleles will be present in dark-keeled heterozygotes and sheltered from the influences of natural selection to a degree far greater than in a diploid. On Flamborough Head (10 km squares 54/26 and 54/27) 
the dark-keel frequency is particularly high, 88 to 96 per cent in six large samples. Assuming that genotype frequencies are at random mating equilibrium proportions, 95 per cent dark-keeled plants implies that the frequency of the light-keel allele is as high as $0 \cdot 47$, and no fewer than 22 per cent of plants will be dark-keeled but triplex for the light-keel allele. Furthermore, the effect of directional selection operating against a recessive allele, at such a frequency is about an order of magnitude less in an autotetraploid compared with a diploid. It is not surprising, therefore, that populations monomorphic for dark keels are effectively absent. In western or southern coastal regions, however, the situation is entirely different. If 5 per cent of plants have dark keels, the expected frequency of the dominant dark-keel allele is only 0.01 . It seems surprising that directional selection against the dark-keeled morph should not lead to more genuine cases of monomorphism for light-keeled plants. It is possible that some form of frequencydependent selection may operate in favour of darkkeeled plants when they are rare, or at least in those areas where they tend to be rare.

Attempts to identify components of selection that influence keel-colour frequencies have been largely unsuccessful (Jones and Crawford, 1977; Jones et al., 1986). It is likely, though, that selective forces and the resulting contributions to fitness differences are not uniform throughout the British Isles. Attention has been concentrated on material from sites where morph frequencies are intermediate, and the results may not apply to regions where one or other morph predominates. In particular, the experiments on pollinator behaviour reported by Jones et al. (1986) used plots with equal morph frequencies; more obvious pollinator preferences might emerge with unequal morph frequencies.

Jones et al. (1986) found some evidence for the earlier flowering of light-keeled plants at two Yorkshire sites, Eppleworth Quarry (54/023327) and Wharram Quarry (44/859653). This suggestion has now been confirmed at six sites near York where in two successive years there was a trend for the frequency of dark-keeled plants to increase during the early stages of the flowering season (fig.6). However, as all eight sites are in Yorkshire, it would be premature to conclude that light-keeled plants, in general, flower earlier. The difference is probably of little evolutionary significance because only a very small proportion of the total seed output originates from the early flowers. Furthermore, although early-ripening seeds produced fewer dark-keeled progeny compared with the later seeds, the germination success of the early seeds was severely depressed (table 4). The majority of the early seeds had soft coats; they imbibed water without scarification, but quickly developed mould and failed to germinate. There is little comparable information against which to judge these results. Stephenson and Winsor (1986) reported 8.3 and $7 \cdot 3$ seeds per pod from their self-thinned inflorescences, followed by a 31 per cent germination rate. Jones et al. (1986) collected 31.704 seeds from 93 plants at Cauldon Lowe Quarry (43/076485); an average of 5.91 seeds per pod yielded only $2 \cdot 31$ progeny per pod with the majority of inviable seeds having soft coats. It is unknown whether the poor quality of early seeds is the rule, either geographically or in different years. Poor weather could influence directly seed development or, more likely, could reduce pollinator activity. During late May and early June 1985 the weather in north-east England was cool and wet except for a brief warm spell at the turn of the month. It is further possible that $L$. corniculatus is relatively unattractive to bees when only a few flowers are available, in which case poor seed quality would be usual for early flowers. The practical significance of these observations is that keel-colour frequencies should not be scored early in the flowering season; neither should seed be collected until there are many ripe pods.

A change in the frequency of the dark-keeled form with time has been observed in Wharram Quarry, which is situated towards the eastern end of the cline in northern England (Compton et al., 1988). During the 1970s the frequency of the darkkeeled form was lower in the quarry than in the surrounding ancient pasture. Since then the darkkeeled form has increased in frequency, with a significant excess of dark-keeled plants occurring in those regions of the quarry with more mature grassland vegetation. Although the seeds were derived from groups of plants with a high frequency of the dark-keeled form, our observations suggest that there was selection in favour of light-keeled plants among the pioneers of the open quarry floor. We do not know the particular feature of a maturing vegetation that could be acting as the selective agent. Although the maturity of the vegetation cannot explain the large-scale clinal variation we have observed in northern England, it could account for local variation, particularly on disturbed land.

As mentioned above, the association of largescale clines in morph frequencies with climatic variation is attractive. This is particularly so when differences in pigmentation are involved. There are, however, no obvious correlations between dark-keel frequency and single major components 
of the British climate as illustrated by, for example, White and Smith (1982). It remains to be seen, though, whether a complex combination of climatic factors can be related to keel-colour morph distribution. Even if an association can be demonstrated, it would provide only weak evidence for causation; but it would be useful for raising hypotheses for more formal testing. Experiments measuring fine-scale temperature differences within keels are in progress. Preliminary results suggest that any differences between the morphs will be small; so small, in fact, that their physiological consequences may not be detectable.

We find it hard to accept that the distribution of the keel-colour morphs could have arisen by chance. We believe, therefore, that the determination of the selective forces involved in this polymorphism provides a major challenge to ecological genetics.

Acknowledgements We are obviously indebted to the many friends, colleagues and members of the general public who have assisted with the survey. Without their enthusiastic help it would not have been possible to cover the British Isles so completely. We thank our families for their tolerance over the years while summer outings and holidays have usually degenerated into Lotus sampling expeditions. In particular, we would like to thank Dr Richard Abbott for providing us with full details of his previously published data, Trina Paskell of the Royal Society for Nature Conservation through whose publicity in The Sunday Times many individuals first heard of the survey, and Harry Vallack who has provided technical support in the field and the laboratory and has drawn all the figures. We gratefully acknowledge receipt of a Small Ecological Project Grant from the British Ecological Society, and the support of the N.E.R.C. at earlier stages of this work.

\section{REFERENCES}

ABBOTT, R. J. 1981. The keel petal colour polymorphism of Lotus corniculatus L. in Scotland. New Phytol., 88, 549-553.

BAKER, K. AND JONES, D. A. 1986. Altitude and the keel petal polymorphism of Lotus corniculatus L. J. Nat. Hist., 20, 1429-1433.

BERRY, R. J. 1977. Inheritance and Natural History. Collins, London.

BISHOP, J. A. 1972. An experimental study of the cline of industrial melanism in Biston betularia (L.) (Lepidoptera) between urban Liverpool and rural North Wales. J. Anim. Ecol., 41, 209-243.

BRAKefield, P. M. AND LeEs, D. R. 1987. Melanism in Adalia ladybirds and declining air pollution in Birmingham. Heredity, 59, 273-277.

CAIN, A. J. AND CURREY, J. D. 1963. Area effects in Cepaea. Phil. Trans. R. Soc. Ser. B, 246, 1-81.

COMPTON, S. G., BEESLEY, S. G. AND JONES, D. A. 1988. Variation in the colour of the keel petals in Lotus corniculatus L. 5. Successional differences in the distribution of darkkeeled plants. Heredity, 61, 235-245.
CRAWFORD, T. J. AND JONES, D. A. 1986. Variation in the colour of the keel petals in Lotus corniculatus L. 2. Clines in Yorkshire and adjacent counties. Watsonia, $16,15-19$.

CREeD, E. R. 1971. Melanism in the two-spot ladybird, Adalia bipunctata, in Great Britain. In Creed, E. R. (ed.) Ecological Genetics and Evolution, Blackwell Scientific Publications, Oxford, pp. 134-151.

DADAY, H. 1954a. Gene frequencies in wild populations of Trifolium repens. I. Distribution by latitude. Heredity, 8 , $61-78$.

DADAY, H. 1954b. Gene frequencies in wild populations of Trifolium repens. II. Distribution by altitude. Heredity, 8 , 377-384.

DADAY, H. 1958. Gene frequencies in wild populations of Trifolium repens. III. World distribution. Heredity, 12, 169184.

DAWSON, C. D. R. 1941. Tetrasomic inheritance in Lotus corniculatus L. J. Genet., 42, 49-72.

DE BOER, G. 1963. Spurn Point and its predecessors. The Naturalist, Oct.-Dec. 1963, 113-120.

DE BOER, G. 1968. A History of the Spurn Lighthouses. East Yorkshire Local History Society, York.

ENDLER, J. A. 1977, Geographic Variation, Speciation and Clines. Princeton University Press, Princeton.

FORD, E. B. 1975. Ecological Genetics, 4th edition. Chapman and Hall, London.

HART, R. H. AND WILSIE, C. P. 1959. Inheritance of a flower character, brown keel tip, in Lotus corniculatus L. Agron. J., 51, 379-380.

HEWITT, G. M. AND BROWN, F. M. 1970. The B-chromosome system of Myrmeleotettix maculatus. V. A steep cline in East Anglia. Heredity, 25, 363-371.

JONES, D. A., COMPTON, S. G., CRAWFORD, T. J., ELLIS, W. M. AND TAYLOR, I. M. 1986. Variation in the colour of the keel petals in Lotus corniculatus L. 3. Pollination, herbivory and seed production. Heredity, 57, 101-112.

JONES, D. A. AND CRAWFORD, T. J. 1977. Variation in the colour of the keel petals in Lotus corniculatus L. 1. The polymorphism in western Europe. Heredity, 39, 313-325.

JONES, J. S., LEITH, B. H. AND RAWLINGS, P. 1977. Polymorphism in Cepaea: a problem with too many solutions? Ann. Rev. Ecol. Syst., 8, 109-143.

KETTLEWELL, H. B. D. 1973 The Evolution of Melanism. Clarendon Press, Oxford.

KeTtLEWElL, H. B. D. AND BERRy, R. J. 1961. The study of a cline. Amathes glareosa Esp. and its melanic $f$. edda Staud (Lep.) in Shetland. Heredity, 16, 403-414.

KOPEC, A. C. 1970. The Distribution of the Blood Groups in the United Kingdom. Oxford University Press, London.

MOURANT, A. E., KOPEC, A. C. AND DOMANIEWSKASOBCZAK, K. 1976. The Distribution of the Human Blood Groups and other Polymorphisms. Oxford University Press, London.

MUGGLETON, J., LONSDALE, D. AND BENHAM, B. R. 1975. Melanism in Adalia bipunctata L. (Col., Coccinellidae) and its relationship to atmospheric pollution. J. appl. Ecol., $12,451-464$

NEW, J. 1958. A population study of Spergula arvensis. I. Two clines and their significance. Ann. Bot. N. S., 22, 457-477.

NEW, J. 1978. Change and stability of clines in Spergula arvensis L. (corn spurrey) after 20 years. Watsonia, 12, 137-143.

OCHAMN, H., JONES, J. S. AND SELANDER, R. K. 1987. Large scale patterns of genetic differentiation at enzyme loci in the land snails Cepaea nemoralis and Cepaea hortensis. Heredity, 58, 127-138. 
OXFORD, G. S. 1985. A countrywide survey of colour morph frequencies in the spider Enoplognatha ovata (Clerck) (Araneae: Theridiidae): evidence for natural selection. Biol. J. Linn. Soc., 24, 103-142.

RAMNANI, A. D. AND JONES, D. A. 1984. Inheritance of the brown keel tip character in Lotus corniculatus L. Bangladesh J. Bot., 13, 52-59.

SOUTHERN, H. N. 1962. Survey of bridled guillemots, 1959-60. Proc. zool. Soc. Lond., 138, 455-472.
STEPHENSON, A. G. AND WINSOR, J. A. 1986. Lotus corniculatus regulates offspring quality through selective fruit abortion. Evolution, 40, 453-458.

WHITE, E. J. AND SMITH R. I. 1982. Climatological Maps of Great Britain. Institute of Terrestrial Ecology, Cambridge.

Williamson, M. H. 1981. Island Populations. Oxford University Press, Oxford. 